\title{
Are BVOC exchanges in agricultural ecosystems overestimated? Insights from fluxes measured in a maize field over a whole growing season
}

\author{
Aurélie Bachy $^{1}$, Marc Aubinet ${ }^{1}$, Niels Schoon ${ }^{2}$, Crist Amelynck ${ }^{2}$, Bernard Bodson ${ }^{3}$, Christine Moureaux ${ }^{1}$, and \\ Bernard Heinesch ${ }^{1}$ \\ ${ }^{1}$ TERRA, Gembloux Agro-Bio-Tech, University of Liège, Gembloux, 5030, Belgium \\ ${ }^{2}$ Royal Belgian Institute for Space Aeronomy, Uccle, 1180, Belgium \\ ${ }^{3}$ AGRO-BIO-CHEM, Gembloux Agro-Bio-Tech, University of Liège, Gembloux, 5030, Belgium \\ Correspondence to: Bernard Heinesch (bernard.heinesch@ulg.ac.be)
}

Received: 19 December 2015 - Published in Atmos. Chem. Phys. Discuss.: 18 January 2016

Revised: 28 March 2016 - Accepted: 29 March 2016 - Published: 28 April 2016

\begin{abstract}
Although maize is the second most important crop worldwide, and the most important C4 crop, no study on biogenic volatile organic compounds (BVOCs) has yet been conducted on this crop at ecosystem scale and over a whole growing season. This has led to large uncertainties in cropland BVOC emission estimations. This paper seeks to fill this gap by presenting, for the first time, BVOC fluxes measured in a maize field at ecosystem scale (using the disjunct eddy covariance by mass scanning technique) over a whole growing season in Belgium. The maize field emitted mainly methanol, although exchanges were bi-directional. The second most exchanged compound was acetic acid, which was taken up mainly in the growing season. Bi-directional exchanges of acetaldehyde, acetone and other oxygenated VOCs also occurred, whereas the terpenes, benzene and toluene exchanges were small, albeit significant. Surprisingly, BVOC exchanges were of the same order of magnitude on bare soil and on well developed vegetation, suggesting that soil is a major BVOC reservoir in agricultural ecosystems. Quantitatively, the maize BVOC emissions observed were lower than those reported in other maize, crops and grasses studies. The standard emission factors (SEFs) estimated in this study $\left(231 \pm 19 \mu \mathrm{g} \mathrm{m}^{-2} \mathrm{~h}^{-1}\right.$ for methanol, $8 \pm 5 \mu \mathrm{g} \mathrm{m}^{-2} \mathrm{~h}^{-1}$ for isoprene and $4 \pm 6 \mu \mathrm{g} \mathrm{m}^{-2} \mathrm{~h}^{-1}$ for monoterpenes) were also much lower than those currently used by models for $\mathrm{C} 4$ crops, particularly for terpenes. These results suggest that maize fields are small BVOC exchangers in north-western Europe, with a lower BVOC emission im-
\end{abstract}

pact than that modelled for growing $\mathrm{C} 4$ crops in this part of the world. They also reveal the high variability in BVOC exchanges across world regions for maize and suggest that SEFs should be estimated for each region separately.

\section{Introduction}

In order to model future climate with high reliability, an indepth understanding of all climate components and their interactions is necessary. Volatile organic compounds (VOCs) are among these components. Although VOCs constitute only a small fraction of the total air composition, their high reactivity has a significant effect on atmospheric chemistry and climate by affecting the methane lifetime in the atmosphere (Isaksen et al., 2009; Williams et al., 2013) and through the formation of secondary organic aerosols (Sartelet et al., 2012; Ziemann and Atkinson, 2012) and tropospheric ozone (Fry et al., 2012; Isaksen et al., 2009; Sartelet et al., 2012; Tsimpidi et al., 2012). The understanding of VOC exchanges is therefore a research priority if better climate and air quality predictions are to be achieved (Lerdau and Slobodkin, 2002; Osborne et al., 2010).

There are numerous VOC sources (e.g., solvents, burning residues, micro-organisms). There is however a general consensus that most atmospheric VOCs originate from biogenic sources (hence the term biogenic VOCs, BVOCs), and particularly from plants (Fowler et al., 2009). 
BVOC exchange composition and dependence on environmental factors are plant species-specific (Monson et al., 2013), and BVOC studies therefore need to broaden the range of investigated plants and ecosystems in order to estimate global BVOC exchanges with more accuracy (Lerdau and Slobodkin, 2002; Niinemets et al., 2014). This is currently not the case, however. Although forests have been the most widely studied ecosystem (see Niinemets et al., 2013 for a review), only a few BVOC studies have focused on croplands (Copeland et al., 2012; Crespo et al., 2013; Eller et al., 2011; Karl et al., 2005; Konig et al., 1995; Warneke et al., 2002). As far as we know, only two BVOC measurement studies have dealt with maize (Das et al., 2003; Graus et al., 2013), although it is the second most important crop in the world in terms of cultivated area (Food and Agriculture Organization of the United Nations Statistics Division, FAOSTATS), and in some regions it is the dominant crop (e.g., the Corn Belt zone in the USA), and it could become even more important in meeting growing food needs (Hardacre et al., 2013) and enhancing biofuel production (Bellarby et al., 2010). Graus et al. (2013) determined the BVOC exchange composition of maize leaves, and estimated the maize BVOC budget by up-scaling and extrapolating the BVOC fluxes they measured to the whole growing season. Das et al. (2003) found large methanol and acetone emissions from maize and suggested that this crop could play an important role in the atmospheric chemistry in regions where it is widely present, e.g. the Corn Belt zone in the USA.

However, both studies were conducted over only a few days and under poorly contrasted weather conditions. Consequently, they were unable to evaluate the relative effects of climate and phenology on BVOC exchanges, so that the current estimated maize BVOC budget is uncertain. Knowledge about BVOC exchanges from maize therefore remains very limited.

In order to fill this scientific gap, this study focused on BVOCs exchanged by maize, based on ecosystem-scale measurements performed over a whole growing season. As far as we know, it is the first study dealing with long-term BVOC measurements on maize. It sought to answer the following questions:

- Which BVOCs are exchanged in a maize field?

- How important is growing maize in terms of BVOC exchanges compared with other agricultural crops?

- What quantity of BVOCs is exchanged in a maize field under standard environmental conditions (standard conditions correspond to the environmental conditions defined for the MEGAN up-scaling model in Guenther et al., 2006)?

\section{Materials and methods}

\subsection{Experimental set-up}

\subsubsection{Site and variety}

The study was carried out on a silage maize (Zea mays L., varieties Prosil and Rocket) field about $398 \times 255 \mathrm{~m}$ at the Lonzée Terrestrial Observatory (LTO) in Belgium $\left(50^{\circ} 33^{\prime} 08^{\prime \prime} \mathrm{N}, 4^{\circ} 44^{\prime} 42^{\prime \prime} \mathrm{E}\right)$ from 17 May to 11 October 2012. The field is on a plateau with a small slope of $1.2 \%$. There is more information about the LTO site in Moureaux et al. (2006).

The maize was sown on 17 May, emerged on 25 May and was harvested by 13 October 2012. Fertilizers were applied on 4 June 2012, and no measurements were taken between 30 May and 8 June 2012 in order to prevent fertilizer pollution of the instruments. During the study, the field was surrounded by sugar beet and there was a silo about $300 \mathrm{~m}$ northwest of the measurement mast. Subsequent analysis did not detect any significant influence of the surrounding crop or silo on the measured fluxes.

\subsubsection{Flux measurements}

The BVOC fluxes were computed every half-hour from high-frequency vertical wind speed and BVOC concentration measurements using the disjunct eddy covariance by mass scanning (DEC-MS) technique, i.e. from the covariance between the vertical component of the wind speed and the BVOC mixing ratio, both variables being measured at high frequency. In this paper, fluxes are expressed per $\mathrm{m}^{2}$ of soil and a positive flux indicates an emission from the ecosystem to the atmosphere.

The vertical wind velocity was measured at $20 \mathrm{~Hz}$ with a 3-D sonic anemometer (Solent Research R3, Gill Instruments Lymington, UK) mounted on a $2.7 \mathrm{~m}$ high mast. Due to maize growth and in order to have a reasonably aerodynamic measurement height, the anemometer was raised to $3.5 \mathrm{~m}$ high from 12 July to 17 August 2012 and to $3.9 \mathrm{~m}$ high from that date to harvest.

The BVOC concentrations were measured with a high sensitivity proton-transfer-reaction mass spectrometer (hs-PTRMS) model (Ionicon Analytick GmbH, Innsbruck, Austria). Ambient air was continuously sampled close to the sonic anemometer through a main sampling line in perfluoroalkoxy alkanes (PFA) (Fluortechnik-Wolf, Esslingen-Berkheim, Germany), 18/20 m long (before and after 12 July 2012, respectively) and with an inner diameter of $6.4 \mathrm{~mm}$ and a flow rate ranging from 13 to $13.5 \mathrm{STPL} \mathrm{min}^{-1}$ (Standard Temperature and Pressure conditions corresponded to $273.15 \mathrm{~K}$ and $101.3 \mathrm{kPa}$ ). In order to prevent water vapour condensation in the main sampling line, which could dissolve some BVOC compounds, the sampling line was thermally insulated and heated on average $2.6^{\circ} \mathrm{C}$ above ambient temper- 
ature. A polytetrafluoroethylene (PTFE) filter (Pall, $47 \mathrm{~mm}$ diameter, 2 micron pore size) was installed $2 / 4 \mathrm{~m}$ (before and after 12 July 2012, respectively) downstream of the main sampling line inlet in order to keep the tube clean. Part of the air flow (0.1 STP L min ${ }^{-1}$ ) was drawn into the hs-PTR-MS through a $1 \mathrm{~m}$ long heated peek capillary with an inner diameter of $1 \mathrm{~mm}$. The hs-PTR-MS and the sub-sampling line were installed in a temperature-controlled shelter $(293 \mathrm{~K})$ $15 \mathrm{~m}$ from the measurement tower. Since no significant impact of the shelter on trace gas fluxes was identified, it was assumed that the distance between the shelter and measurement tower was enough to prevent wind distortion by the shelter from having a significant impact on wind conditions near the measurement tower.

\subsubsection{Ancillary measurements}

$\mathrm{H}_{2} \mathrm{O}$ fluxes, friction velocity $u_{*}$ and micro-meteorological variables were measured together with BVOC fluxes at a half-hourly scale. $\mathrm{H}_{2} \mathrm{O}$ fluxes were measured using the conventional eddy covariance technique, with the same sonic anemometer as for BVOCs and a closed-path infrared gas analyzer (IRGA, Li-7000, LI-COR, Lincoln, NE, USA). $u_{*}$ was measured with the sonic anemometer. Monitored meteorological variables relevant to this study were photosynthetic photon flux density (PPFD) (BF3, Delta_T Devices Ltd, Cambridge, UK), air temperature $(T)$ (RH T2, Delta_T Devices Ltd, Cambridge, UK) and relative humidity (RH) (RH T2). See Aubinet et al. (2009) for more information about the non-BVOC experimental set-up.

The phenological development of the maize was followed up through weekly site visits and from pictures taken every day with a phenological camera. Biomass and leaf area index (LAI) were measured on seven and four dates, respectively, between the end of June and the harvest. The evolutions of the biomass and the LAI during the maize growing season were then evaluated by fitting a sigmoid function to the data. In addition, biomass and LAI were set at zero before maize emergence and set at their maximal value after 20 August 2012, in line with field observations.

\subsection{PTR-MS operation}

The hs-PTR-MS instrument was operated in the multiple ion detection mode. Thirteen different ion species, of which 11 were related to BVOCs (Table 1), were measured in a single measurement cycle. The dwell time for each ion species was $0.2 \mathrm{~s}$ and the total cycle time was $3.25 \mathrm{~s}$.

The hs-PTR-MS was operated with a drift tube pressure of $2.1 \mathrm{hPa}$, a drift tube temperature of $333 \mathrm{~K}$ and a drift voltage of $600 \mathrm{~V}$. The instrumental background was determined for $20 \mathrm{~min}$ every $4 \mathrm{~h}$ by switching the hs-PTR-MS inlet flow from ambient air to BVOC-free air, which was obtained by sending ambient air through a heated catalytic converter. Only the final $8 \mathrm{~min}$ were used for calculating the mean background values. The sensitivity of the instrument was calibrated every 2-3 days using a gravimetrically prepared mixture of BVOC gases in $\mathrm{N}_{2}$ (Apel-Riemer Environmental, Denver, CO, USA). The initial mixture, containing about 1 ppmv methanol, acetaldehyde and acetone and about 0.5 ppmv acetonitrile, isoprene, methyl vinyl ketone (MVK), methacrolein (MACR), methyl ethyl ketone (MEK), $\alpha$-pinene and sabinene, with an accuracy of $5 \%$, was used until 22 May 2012. From that date on, a second mixture containing about 1 ppmv methanol, acetaldehyde, MEK and cis-3-hexenol and about 0.5 ppmv acetonitrile, acetone, isoprene, MACR, MVK, benzene, toluene, m-xylene, $\alpha$-pinene and sabinene, with an accuracy of $5 \%$, was used instead. The compounds were further diluted (2-12 ppbv range) using a dynamic dilution system. Additionally, three calibrations as a function of relative humidity were performed during the study.

In this study, it was assumed that only acetone and acetic acid contributed to the $\mathrm{m} / \mathrm{z} 59$ and 61 ion signals, respectively. The calibration factor for acetic acid was estimated from the experimentally determined one for acetone by taking into account the fragmentation of the protonated molecules in the drift tube (Inomata and Tanimoto, 2010; Schwarz et al., 2009) and the ratio of the calculated collision rate constants $(\mathrm{Su}, 1994)$ and by assuming the same transmission efficiency for ions at $m / z 59$ and 61 .

The $m / z 69$ signal (M69) is commonly associated to protonated isoprene in hs-PTR-MS BVOC studies, but it may also result from dissociative proton transfer to other BVOCs (Table 1). M69 emissions were observed on bare soil (Fig. 1, the soil is bare during the stage $\mathrm{G}$ as explained in Table 2), but they did not significantly increase with $T$ or PPFD (data not shown), indicating that they probably did not originate from isoprene sources during that period, as isoprene emissions are known to be strongly influenced by those driving variables (Niinemets et al., 2013). However, when the crop developed, M69 emissions did increase with $T$ and PPFD (data not shown) and could therefore, at least partly, be due to isoprene. Since our experimental set-up did not allow unambiguous identification of the compounds resulting in M69 fluxes, the calibration factor for isoprene was used in the M69 flux calculation. The M69 fluxes were therefore considered as an upper isoprene flux limit for all phenological stages apart from $\mathrm{G}$.

The ion signal at $m / z 83$ was measured in order to represent green leaf volatiles (GLV, Table 1) and to evaluate the maize stress status. The observed exchanges were qualitative, however, and therefore this signal is not discussed in this paper.

In order to compare the water vapour fluxes obtained with the hs-PTR-MS and the IRGA, the hs-PTR-MS ion signal at $m / z 39$ (M39), a water vapour proxy, was post-calibrated using the mean half-hourly $\mathrm{H}_{2} \mathrm{O}$ concentration derived from the RH measurements $\left(R^{2}=0.97\right)$, as described by Ammann et al. (2006). 
Table 1. $m / z$ ratio of ion species measured at LTO and their potentially contributing compounds.

\begin{tabular}{rll}
\hline$m / z$ & Ion species & Potentially contributing compounds \\
\hline 21 & $\mathrm{H}_{3}^{18} \mathrm{O}^{+}$ & 3rd isotope of the 1st proton hydrate \\
33 & $\mathrm{CH}_{5} \mathrm{O}^{+}$ & Methanol \\
39 & $\mathrm{H}_{5}^{16} \mathrm{O}^{18} \mathrm{O}^{+}$ & 3rd isotope of the 2nd proton hydrate \\
45 & $\mathrm{C}_{2} \mathrm{H}_{5} \mathrm{O}^{+}$ & Acetaldehyde (ACD) \\
59 & $\mathrm{C}_{3} \mathrm{H}_{7} \mathrm{O}^{+}$ & Acetone, propanal \\
61 & $\mathrm{C}_{2} \mathrm{H}_{5} \mathrm{O}_{2}^{+}$ & Acetic acid \\
69 & $\mathrm{C}_{5} \mathrm{H}_{9}^{+}$ & Isoprene, methyl butenols, pentenols, methyl butanal \\
71 & $\mathrm{C}_{4} \mathrm{H}_{7} \mathrm{O}^{+}$ & Methyl vinyl ketone (MVK), methacrolein (MACR), pentanol \\
73 & $\mathrm{C}_{4} \mathrm{H}_{9} \mathrm{O}^{+}$ & Methyl ethyl ketone (MEK) \\
79 & $\mathrm{C}_{6} \mathrm{H}_{7}^{+}$ & Benzene \\
83 & $\mathrm{C}_{6} \mathrm{H}_{11}^{+}$ & Hexenols, hexenyl acetates, hexanal \\
93 & $\mathrm{C}_{7} \mathrm{H}_{9}^{+}$ & Toluene \\
137 & $\mathrm{C}_{10} \mathrm{H}_{17}^{+}$ & Monoterpenes (MT) \\
\hline
\end{tabular}

Table 2. Maize phenological development. BBCH codification refers to Meier (2001). Both biomass and LAI refer to the beginning of a stage.

\begin{tabular}{|c|c|c|c|c|c|c|}
\hline & Stage & Date & $\mathrm{BBCH}$ & $\begin{array}{r}\text { Biomass } \\
{\left[\mathrm{g} \mathrm{m}^{-2}\right]}\end{array}$ & $\begin{array}{r}\text { LAI } \\
{\left[\mathrm{m}^{2} \mathrm{~m}^{-2}\right]}\end{array}$ & Description of maize development \\
\hline \multirow{6}{*}{$\begin{array}{l}\text { Vegetative } \\
\text { growth }\end{array}$} & $\mathrm{G}$ (germination) & 14 May-4 June & $00-14$ & 0 & 0.00 & From sowing to 4-leaf stage \\
\hline & & & & & & Emergence on 25 May \\
\hline & & & & & & $\begin{array}{l}\text { Considered as bare soil throughout the stage due to } \\
\text { small biomass and biomass growth }\end{array}$ \\
\hline & $\mathrm{L}$ & 5-26 June & $14-16^{\mathrm{a}}$ & 49 & 0.01 & From 4-leaf to 6-leaf stage \\
\hline & (leaf unfolding) & & & & & Progressive canopy closure \\
\hline & $\begin{array}{l}\text { S } \\
\text { (leaf area development } \\
\text { and stem elongation) }\end{array}$ & 27 June- 5 August & $30-39$ & 152 & 0.10 & $\begin{array}{l}\text { From 6-leaf stage to panicle emergence } \\
\text { Important increase in leaf area, maize height and } \\
\text { biomass }\end{array}$ \\
\hline \multirow{6}{*}{$\begin{array}{l}\text { Reproductive } \\
\text { growth }\end{array}$} & $\mathrm{R} 1$ & 6-29 August & $51-71(73)^{\mathrm{b}}$ & 806 & 4.30 & From panicle emergence to fruit maturation \\
\hline & (inflorescence and fruit & & & & & Stamen appearance by 10 August (BBCH 61) \\
\hline & development) & & & & & $\begin{array}{l}\text { Max. LAI reached by } 20 \text { August }\left(5.06 \mathrm{~m}^{2} \mathrm{~m}^{-2}\right) \\
\text { Important biomass increase }\end{array}$ \\
\hline & \multirow{3}{*}{$\begin{array}{l}\mathrm{R} 2 \\
\text { (fruit maturation) }\end{array}$} & \multirow[t]{3}{*}{29 August-12 October } & \multirow[t]{3}{*}{$71(73)^{b}-89^{c}$} & 1539 & \multirow[t]{3}{*}{5.06} & From fruit maturation to harvest \\
\hline & & & & & & Intermediate biomass increase \\
\hline & & & & $2019.2^{\mathrm{d}}$ & & \\
\hline
\end{tabular}

a Stages 17 to 19 did not occur.

b Estimation: Fruit visible at the end of the stage, but exact grain maturity not identifiable.

c Stages 97 and 99 did not occur. ${ }^{d}$ Harvest

\subsection{BVOC flux computation}

The general BVOC flux computation framework drew on the EUROFLUX methodology (Aubinet et al., 1999), which is designed for $\mathrm{CO}_{2}$ flux measurements using the conventional EC technique. It was adapted for DEC-MS and low flux signal-to-noise ratio specificities when relevant. Means were computed using block averaging over 30 min periods and a 2-D rotation was applied. The time lag between the wind and the concentration data streams was calculated using the technique recommended by Bamberger et al. (2010), Hörtnagl et al. (2010) and Taipale et al. (2010), whereby time lags and fluxes are determined by covariance maximisation, using the disjunct concentrations (so without imputation) to compute the cross-correlation curve and applying a smooth- ing function (a $3 \mathrm{~s}$ window size was chosen) to that curve prior to peak determination. The time lag mode found for methanol was $5.25 \mathrm{~s}$, close to the M39 time lag mode (5.45 s) and to the theoretical time lag determined in situ by isopropylalcohol injection $(5 \pm 0.5 \mathrm{~s})$. No mode was found for the other compounds investigated. A default value of $5.25 \mathrm{~s}$ was used when the maximal covariance was not found within the [2.75-7.75] s time window (between 49 and $78 \%$ of the data depending on the compound).

A frequency response correction accounting for low-pass filtering was applied on eddy flux data. The approach described by Moncrieff et al. (1997) was used, whereby each instrumental effect is modelled using a theoretical transfer function. The total transfer function was characterized by a half-power cut-off frequency of $0.4 \mathrm{~Hz}$ and was combined 

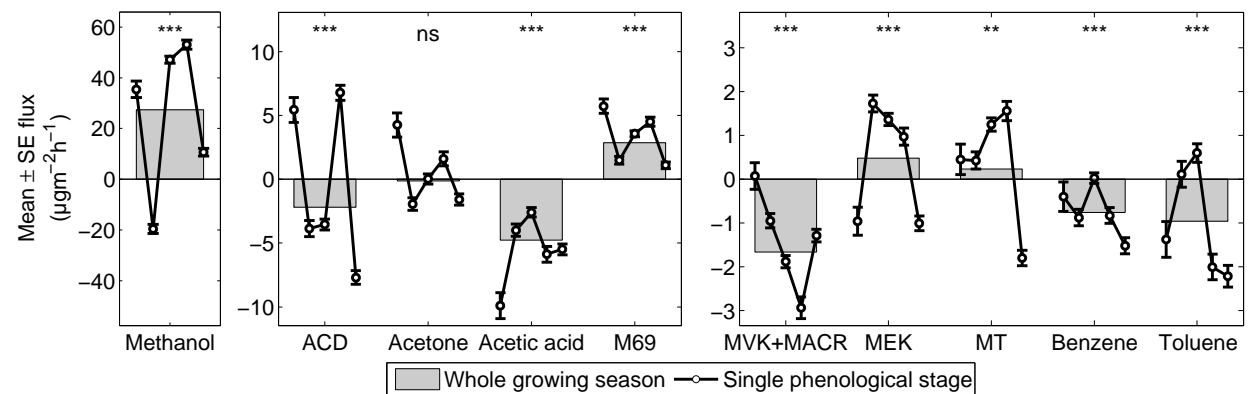

Figure 1. BVOC exchanges over the growing season. Phenological stages, from left to right: G, L, S, R1 and R2. Stars indicate the significance level of flux averages over the whole growing season. See Table 1 for compound abbreviations and Table 2 for phenological stage description. Note the varying scales used for the $y$ axes.

with the theoretical Kaimal co-spectrum, which is very close to the experimental sensible heat co-spectra (Kaimal and Finnigan, 1994), in order to determine a correction factor to apply to the fluxes. This factor ranged between 1 and 2, with a mean value of 1.29 .

\subsection{BVOC flux filtering}

BVOC fluxes were discarded when the maize field contribution to the total flux footprint (Neftel et al., 2008) was below $70 \%$ ( $2 \%$ of the whole data set), during hs-PTR-MS calibration and background measurement periods $(22 \%)$, when the flux measurement system was stopped because of maintenance operations $(1 \%)$, power failures $(9 \%)$ or spraying events $(6 \%)$, and when the fluxes were not computed because concentration or sonic anemometer data were not available (9\%). This resulted in 3592 valid half-hourly flux data for each investigated compound (51\% of the whole data set).

It should be noted that we did not filter BVOC fluxes below a certain $u_{*}$ threshold or according to stationarity. Theoretically, for non-soluble compounds, when measuring fluxes by the EC technique, flux data which were measured at $u_{*}$ values below a certain threshold must be discarded (Aubinet et al., 2012). However, we did not apply this specific filtering criterion because $u_{*}$ can actually control soluble BVOC fluxes (Aubinet et al., 2012; Laffineur et al., 2012). Moreover we observed that $u_{*}$ induced a higher flux random error, but not a systematic error. For all the investigated compounds, both daytime and nighttime fluxes presented a conical shape when plotted against $u_{*}$ with the flux range increasing along with $u_{*}$. The flux detection limit (Sect. 2.5.2) was also positively well correlated with $u_{*}$, with $R^{2}$ ranging from 0.51 to 0.80 , depending on the compound. In addition, the correlation between the $\mathrm{H}_{2} \mathrm{O}$ fluxes measured with the IRGA and those measured with the hs-PTR-MS (M39) improved with decreasing $u_{*}$. Even if the random error increased with $u_{*}$, however, the mean exchanges of non-soluble compounds, evaluated by averaging fluxes per $u_{*}$ class, did not significantly differ with $u_{*}$. This means that low $u_{*}$ values did not create biased BVOC fluxes. Consequently, we did not apply a low $u_{*}$ threshold to those fluxes.

The stationarity criteria designed for the conventional EC technique (Aubinet et al., 2012) and commonly used in BVOC flux studies were irrelevant for the BVOC fluxes measured at LTO. Stationarity filtering criteria calculated from M39 data (using the approach described by Foken and Wichura, 1996) did not remove the same data as those calculated from the IRGA $\mathrm{H}_{2} \mathrm{O}$ data. In addition, for all the investigated BVOC compounds, both stationary and nonstationary data had similar diurnal dynamics and were correlated with the same environmental variables, suggesting that non-stationary data were not abnormal. Therefore, we did not apply that filtering criterion to the BVOC fluxes.

\subsection{BVOC flux error evaluation}

\subsubsection{Systematic error}

The possible occurrence of a systematic error in the calculated BVOC fluxes was evaluated by (i) computing the flux distribution for each compound and (ii) comparing the $\mathrm{H}_{2} \mathrm{O}$ turbulent fluxes computed from M39 with those computed from the IRGA data, following the approach used by Ammann et al. (2006).

The half-hourly flux distribution was quite symmetric around zero for each compound. No mirroring effect (Langford et al., 2015) was observed, indicating that the chosen time lag method did not create bias in the flux. Moreover, the M39 fluxes correlated well with the $\mathrm{H}_{2} \mathrm{O}$ fluxes measured with the IRGA, even though the determination coefficient was lower $\left(R^{2}=0.71\right)$ than the one reported by Ammann et al. (2006) $\left(R^{2}=0.92\right)$. The regression slope did not significantly differ from 1 , indicating that the $\mathrm{H}_{2} \mathrm{O}$ fluxes calculated with the DEC-MS technique were not biased. Consequently, we considered that the BVOC fluxes measured at LTO were not biased. 


\subsubsection{Random error}

An individual 30 min flux random error was equated with its detection limit. The latter was computed as the standard deviation $\sigma$ of the covariance function on a time lag window far from the theoretical time lag and therefore physically irrelevant, following the approach used by Spirig et al. (2005). Depending on the compound, 63 to $86 \%$ of the flux data were above the detection limit (moving to 15 and to $60 \%$ when $3 \sigma$ was taken, as proposed by some authors). Langford et al. (2015) found that the root mean square (RMS) of the covariance function was a better estimator of the flux random error than $\sigma$. When the RMS was compared with $\sigma$ for fluxes measured in June 2012, however, we did not observe any significant differences (data not shown). The standard deviation method was therefore retained.

Although many BVOC fluxes were lying above their detection limit, flux data performed at the half-hourly scale were very scattered (except for methanol flux). Thus, in all analyses, fluxes were averaged over many observations during a specific period, typically the whole growing season or a phenological stage.

\subsection{BVOC budget computation}

The BVOC budget was computed over the whole maize growing season for each compound separately, using the method recommended by Bamberger et al. (2014), with gaps smaller than or equal to $2 \mathrm{~h}$ ( $23 \%$ of the whole data set) filled by linear interpolation, and gaps larger than $2 \mathrm{~h}(26 \%)$ filled using the mean diurnal variation (MDV) technique, with a 16-day window size centered on the missing data.

The budget error was evaluated by flux error propagation. The flux detection limit $\left(1^{*} \sigma\right)$ was used as the flux random error for measured fluxes. As gap-filled fluxes were determined from measured fluxes, the random error of each individual gap-filled flux was evaluated by propagating the error of the fluxes used to estimate that flux.

The error caused by the gap-filling technique itself was not quantified, but we argue that budgets reported in this paper are consistent for their order of magnitude. First, the gapfilling did not change the BVOC flux pattern. Then, when estimating flux data for gaps smaller than $2 \mathrm{~h}$, the use of interpolation techniques other than linear resulted in flux values that were not significantly different from those obtained with linear interpolation. Thirdly, the MDV technique which was used to estimate fluxes in larger gaps has been shown to result in fewer errors than other gap-filling techniques (Bamberger et al., 2014). In addition, most gaps lasted less than 1 day. Eight gaps exceeded 1 day; four of them lasted less than 2 days, and three of them lasted between 3 and 4 days. Only one gap lasted 10 days because of a spraying event. The uncertainty induced in the budget when estimating missing flux data for that gap was evaluated by filling all missing data either with the lowest or with the highest flux values mea- sured within 1 month window size around the missing data. These extreme flux data induced a variation up to $257,51,39$ and $53 \mathrm{~g}_{\mathrm{BVOC}} \mathrm{ha}^{-1}$ in the methanol, acetaldehyde, acetone and acetic acid budgets, respectively. Although the budget was significantly modified (Table 5), its order of magnitude remained similar. Moreover, filling all missing data with extremely low or high flux is realistic only if weather conditions were particularly warm and dry or wet and cold when the gap occurred and if they remained constant during the whole gap duration, which was not the case at LTO. Indeed, a warm and dry period occurred during the first 5 days of the gap and was followed by a wetter and colder period during the 5 other days. Consequently, the BVOC budget that actually occurred during that period was certainly less extreme than the BVOC budget estimated by considering extreme flux values and therefore closer to the budget estimated using the MDV technique.

\section{Results and discussion}

\subsection{Maize phenological development}

The maize growing season was divided into five distinct phenological periods: $\mathrm{G}$ (germination - $\mathrm{BBCH} 00$ to 14 ; $\mathrm{BBCH}$ stands for Biologische Bundesanstalt, Bundessortenamt and CHemical industry and is a decimal scale used to identify the developmental stages of plant species); L (leaf unfolding - BBCH 14 to 16); S (stem elongation and leaf area development - BBCH 30 to 39); R1 (inflorescence development, flowering and grain emergence - $\mathrm{BBCH} 51$ to 71); and R2 (grain maturation - BBCH 71 to 89). All the stages were determined by visual observations of the maize field, with the exception of the pivotal date between the stages R1 and R2, which was based on the difference in daily biomass growth because the visual observations were not good enough to determine when $\mathrm{R} 1$ ended and $\mathrm{R} 2$ began.

A detailed description of all the stages and their correspondence with BBCH codification (Meier, 2001) is given in Table 2. Briefly, the ecosystem consisted of bare soil in stage $\mathrm{G}$. The maize developed during the other stages, and so the ecosystem included both soil and plants. Vegetative growth (i.e., leaves and stem) occurred during stages $\mathrm{L}$ and S. Reproductive growth (i.e., flowers and grains) occurred during stages R1 and R2. Vegetative growth was small (R1) to negligible (R2) during the reproductive growth period. It should be noted that, as the maize variety grown at LTO is a "stay green" variety, it was harvested before entering in senescence, and therefore the senescence phase was not included in the phenological description.

\subsection{BVOCs exchange composition at LTO and qualitative comparison with other crops}

Throughout the study, methanol was the main compound exchanged (Fig. 1), ranging from 31 to $76 \%$ of the total mean 

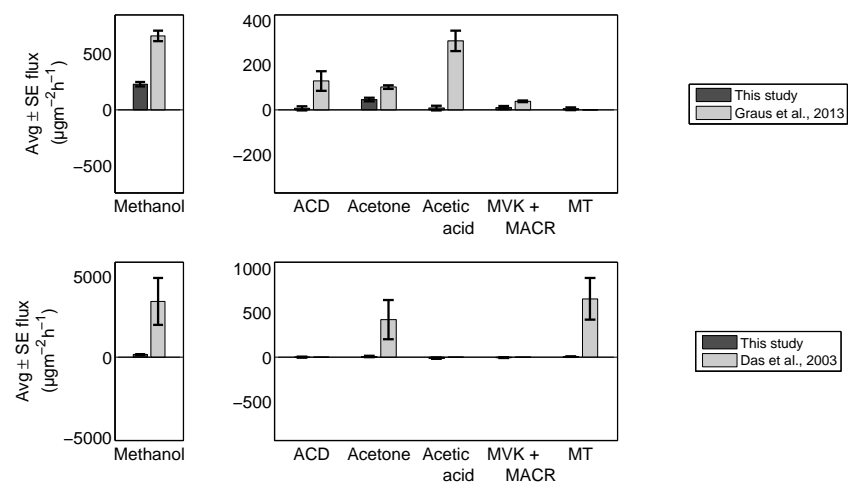

Figure 2. Comparison of BVOC exchanges at LTO with other maize studies. For comparison with Graus et al. (2013): R1 stage, $28^{\circ} \mathrm{C} \leq$ $T^{\circ} \leq 32^{\circ} \mathrm{C} ;$ PPFD $\geq 1000 \mu \mathrm{mol} \mathrm{m}^{-2} \mathrm{~s}^{-1}$. BVOC exchanges reported by Graus et al. (2013) were up-scaled with LAI measured at LTO during the R1 stage $\left(4.86 \mathrm{~m}^{2} \mathrm{~m}^{-2}\right)$. For comparison with Das et al. (2003): $\mathrm{L}$ and S stages, $24^{\circ} \mathrm{C} \leq T^{\circ} \leq 28^{\circ} \mathrm{C}$, fluxes taken from 10:30 to $13: 30$ UTC in order to capture midday fluxes. See Table 1 for compound abbreviations and Table 4 for maize studies description. Note the varying scales for the $y$ axes.

BVOC exchanges (Table 3, all percentages are given in mass basis). Methanol emissions were observed for all stages apart from $L$, which was characterized instead by uptakes resulting from wetter and colder conditions (data not shown).

Apart from methanol, other oxygenated VOCs (OVOCs; in this paper, this includes methanol, acetic acid, acetaldehyde, acetone, MVK+MACR and MEK) were exchanged. The acetic acid, acetaldehyde, acetone, MVK+MACR and MEK contributions to the total BVOC exchange ranged from 0 to $22 \%$ during the phenological stages. Acetic acid, in particular, was the second most important compound exchanged over the growing season, contributing up to $16 \%$ of the total exchange for a single phenological period. It was taken up by the ecosystem throughout the growing season, apart from some days during stage R1 which were characterized by warm and dry conditions and during which small but significant acetic acid emissions were observed instead (Fig. 2). Acetaldehyde and acetone fluxes were important during phenological stages, with contribution up to $22 \%$ for acetaldehyde and $7 \%$ for acetone, but their exchanges varied in magnitude and direction among the phenological stages, resulting in a small acetaldehyde uptake (5\%) and a non-significant acetone exchange over the whole growing season. Small but significant MVK+MACR uptake occurred over the whole growing season, accounting for up to $4 \%$ of the total BVOC exchange. Uptake was more pronounced in stage R1, probably due to higher mixing ratios during that period (up to $1.2 \mathrm{ppbv}$ as opposed to $0-0.4 \mathrm{ppvb}$ for other stages), which favoured dry deposition mechanisms (Niinemets et al., 2014; Tani et al., 2010). MEK was emitted from stages L to R1 and was taken up during the other stages. MEK exchanges were always significant, but never exceeded $5 \%$ of the total BVOC exchange.

Terpenes exchanges (in this paper, terpenes include monoterpenes and isoprene, the maximal exchange rate for the latter being estimated from M69 fluxes for all stages apart from G, Sect. 2.2) were 1 order of magnitude smaller than methanol exchanges and contributed up to $9 \%$ to the total BVOC exchange for a single compound. Significant emissions were found for both compounds during all stages, apart from R2, during which the monoterpenes have been taken up by the maize field ecosystem.

Small but significant benzene and toluene uptake was observed for all phenological stages. Each compound contributed up to $7 \%$ to the total BVOC exchange.

Qualitatively, the BVOC exchange composition observed at LTO matched those observed on diverse croplands and grasslands fairly well. The preponderance of methanol emissions over all other BVOCs has been reported in numerous cropland and grassland studies (Bamberger et al., 2010; Copeland et al., 2012; Crespo et al., 2013; Custer and Schade, 2007; Eller et al., 2011; Ruuskanen et al., 2011; Warneke et al., 2002), including maize studies (Das et al., 2003; Graus et al., 2013). Smaller (compared with methanol exchanges) but significant bi-directional exchanges of other OVOCs and terpenes were also reported in those studies.

The maize field at LTO was not an important monoterpene source, in contrast to the observation reported from an American maize field (Das et al., 2003). It was also a small toluene and benzene sink, whereas both compounds were found to be emitted by maize leaves in another study (Graus et al., 2013). In addition, our observations disagree with the hypothesis proposed by White et al. (2009) that maize could be an important toluene source.

Lastly, each investigated BVOC showed different seasonal dynamics, indicating that the sources, sinks strength and/or exchange mechanisms differed for each compound.

\subsection{Role of soil in BVOC exchanges at LTO}

The soil played an important role in the BVOC exchanges at LTO. Bare soil (stage G) showed emissions of methanol, acetaldehyde and acetone, and the strongest acetic acid uptake occurred during this stage.

It was reported by Schade and Custer (2004) that agricultural soils emit methanol and acetone under warm conditions. The maximal methanol $\left(335 \mu \mathrm{g} \mathrm{m}^{-2} \mathrm{~h}^{-1}\right)$, acetone $\left(136 \mu \mathrm{g} \mathrm{m}^{-2} \mathrm{~h}^{-1}\right)$ and acetaldehyde $\left(102 \mu \mathrm{g} \mathrm{m}^{-2} \mathrm{~h}^{-1}\right)$ emissions recorded at our site in stage $G$ were smaller than the maximal emission values found by these authors (Table 4), but they were all within the range of the maximal emissions reported in the review of Peñuelas et al. (2014), i.e., 3-553 $\mu \mathrm{g} \mathrm{m}^{-2} \mathrm{~h}^{-1}$ for methanol, 4-806 $\mu \mathrm{g} \mathrm{m}^{-2} \mathrm{~h}^{-1}$ for acetone and $1.7-102 \mu \mathrm{g} \mathrm{m}^{-2} \mathrm{~h}^{-1}$ for acetaldehyde.

Interestingly, however, the methanol and acetaldehyde fluxes measured at our site were of the same order of mag- 
Table 3. BVOC composition per phenological stage. Each percentage corresponds to the ratio of the absolute mean flux of a particular compound during a phenological stage to the sum of the absolute mean fluxes of all investigated compounds during that stage.

\begin{tabular}{lrrrrrr}
\hline & $\mathrm{G}$ & $\mathrm{L}$ & $\mathrm{S}$ & $\mathrm{R} 1$ & $\mathrm{R} 2$ & Whole season \\
\hline Methanol & $55 \%$ & $56 \%$ & $76 \%$ & $66 \%$ & $31 \%$ & $66 \%$ \\
Acetaldehyde & $8 \%$ & $11 \%$ & $5 \%$ & $8 \%$ & $22 \%$ & $5 \%$ \\
Acetone & $7 \%$ & $6 \%$ & $0 \%$ & $2 \%$ & $5 \%$ & $0 \%$ \\
Acetic acid & $15 \%$ & $11 \%$ & $4 \%$ & $7 \%$ & $16 \%$ & $12 \%$ \\
M69 & $9 \%$ & $4 \%$ & $6 \%$ & $6 \%$ & $3 \%$ & $7 \%$ \\
MVK+MACR & $0 \%$ & $3 \%$ & $3 \%$ & $4 \%$ & $4 \%$ & $4 \%$ \\
MEK & $2 \%$ & $5 \%$ & $2 \%$ & $1 \%$ & $3 \%$ & $1 \%$ \\
Monoterpenes & $1 \%$ & $1 \%$ & $2 \%$ & $2 \%$ & $5 \%$ & $1 \%$ \\
Benzene & $1 \%$ & $3 \%$ & $0 \%$ & $1 \%$ & $4 \%$ & $2 \%$ \\
Toluene & $2 \%$ & $0 \%$ & $1 \%$ & $3 \%$ & $7 \%$ & $2 \%$ \\
\hline
\end{tabular}

nitude for bare soil as for fully developed vegetation (R1), both stages occurring under similar weather conditions, and the highest acetone emissions occurred during stage G. This means that soil BVOC exchanges were as important, if not more so, as plant BVOC exchanges at LTO. This observation goes against the current assumption that plant BVOC exchanges dominate soil BVOC exchanges (Peñuelas et al., 2014), at least for our ecosystem.

It has been shown that maize leaves emit methanol, acetone and acetaldehyde (Graus et al., 2013). Moreover, significant methanol, acetone and acetaldehyde emissions have been measured in controlled chambers from maize leaves of the "Prosil" variety (A. Mozaffar, personal communication, 2015), which is one of the two varieties grown at LTO. At ecosystem-scale, BVOC exchanged by maize should therefore increase along with plant development and associated biomass increases, and lead to higher methanol, acetone and acetaldehyde emissions during stage R1, compared with stage G, but this was not the case at LTO. We therefore conclude that, at least for those compounds, the soil source strength decreased during the maize growing season at LTO and thus reduced the importance of the soil in the total net measured BVOC exchange.

\subsection{Importance of maize as a BVOC exchanger compared with other crops}

\subsubsection{Quantitative comparison of BVOCs exchange rates at LTO with other maize BVOC studies}

So far as we know, there have been only two other BVOC studies focusing on maize. They were conducted in the USA over a few days and under particular weather conditions (Table 4).

We averaged the BVOC fluxes gathered at LTO under similar $T$, PPFD and phenological stages as the American studies in order to exclude as far as possible the phenological and meteorological effects on BVOC exchanges (Fig. 2). The results showed that BVOC fluxes were much lower at LTO than in the two other maize studies, differing by a factor of 3 to 43 compared to Graus et al. (2013), depending on the compound, and by 2 orders of magnitude compared to Das et al. (2003).

The mean exchanges reported by Graus et al. (2013) arose from leaf-scale measurements performed in controlled chambers. They were therefore affected by up-scaling issues and probably differed from the mean exchanges that would have been measured at their site at ecosystem scale and under natural environmental conditions. It is thus possible that the discrepancies with our observations result from differences in experimental design.

In contrast, the BVOC flux study by Das et al. (2003) was conducted at ecosystem-scale under natural conditions. Their flux measurement technique (gradient) differed from the one we used (DEC-MS), but it has been shown in other BVOC flux measurement studies that both techniques lead to similar BVOC exchange magnitudes (Park et al., 2014; Karl et al., 2001). The two orders of magnitude difference in BVOC exchanges between their study and ours therefore reflects real and significant differences in BVOC exchanges between the two sites.

In this comparison, the BVOC exchanges have been normalized by $T$, PPFD and phenology. Other environmental conditions (e.g., humidity, soil type, soil fertility), as well as cultural regional practices (e.g., chosen maize variety, cultural management such as fertilizer use, irrigation), could, however, directly influence the BVOC exchange magnitude through constitutive or stress-induced pathways. They could also affect maize growth and phenology and therefore indirectly influence BVOC exchanges. Given the huge differences in normalized BVOC exchange rates among studies, we conclude that some of these other environmental conditions play a major role in the amount of BVOCs exchanged in a maize field, and therefore that BVOC exchange rates obtained for maize in one region cannot be extrapolated to another region simply by normalizing $T$ and PPFD. We also conclude that the importance of maize fields in BVOC exchanges varies strongly among regions of the world and 


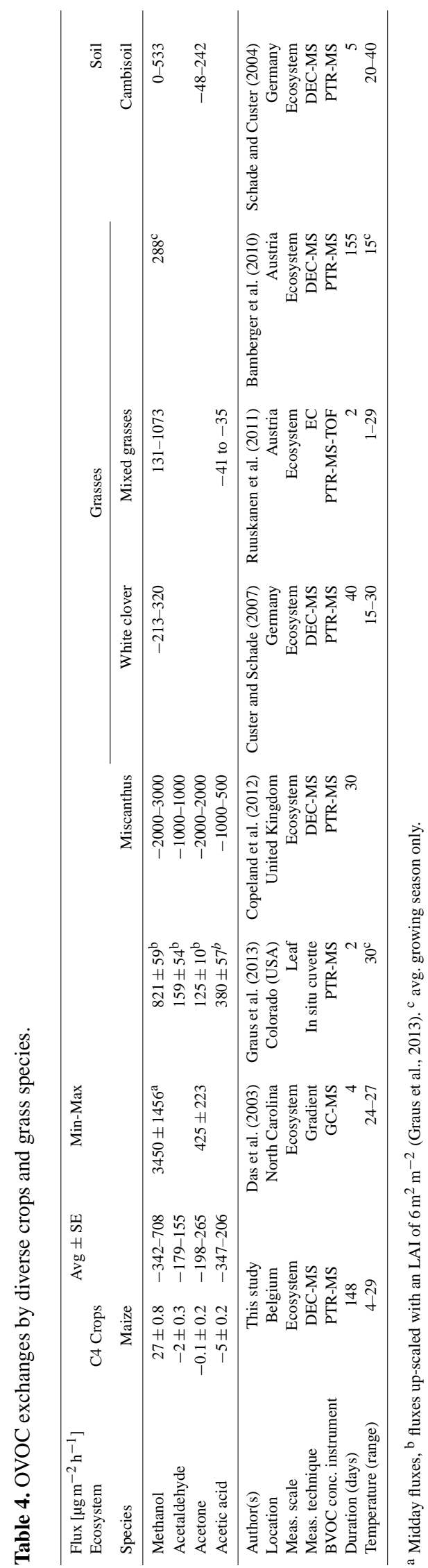

therefore, in the next section, we will compare the BVOC exchanges measured at LTO only with those reported for other crops grown in Europe.

\subsubsection{Quantitative comparison of BVOCs exchange rates at LTO with other crops}

The BVOCs exchanged at LTO were compared with diverse $\mathrm{C} 4$ and $\mathrm{C} 3$ crops and with mixed grassland species. Grasslands were included because their BVOC exchange composition is qualitatively similar to that of crop species (Bamberger et al., 2010; Crespo et al., 2013; Graus et al., 2013; Custer and Schade, 2007; Eller et al., 2011). It should be noted that, as this study focused on BVOC exchanged during the maize growing season, only BVOC exchanges reported for other crops during their growth period were taken into account, i.e., harvest-induced emissions were not considered for comparison.

In our opinion, a comparison of BVOC budgets is the best way to evaluate the relative importance of a crop in terms of BVOC exchanges, because the duration of growing seasons differs greatly from one crop to another (and also under different cultural conditions for the same crop). We reported in Table 5 the budget estimated for the maize field at LTO. The limited information on BVOC budgets that we found in the literature for other crops and grasses (also listed in Table 5), however, does not allow us to draw conclusions about the relative importance of maize in our region. The budgets reported by Crespo et al. (2013) and Graus et al. (2013) relate to different regions, in addition to which they were estimated from BVOC flux measurements conducted over a few days and under a narrow range of weather conditions, making them highly uncertain. The budget reported by Bamberger et al. (2014) includes grass-cutting events, whereas harvestinduced BVOC emissions were not considered at LTO.

We therefore compared the BVOC flux ranges and averages obtained at LTO with those of other European croplands and grasslands (Table 4). From the little information we found, we observed that for all investigated compounds the flux range observed at LTO was more than twice as low as that observed for Miscanthus (Copeland et al., 2012), another $\mathrm{C} 4$ crop. In addition, the methanol flux average measured at LTO was 9 times lower than that observed for a grassland (Bamberger et al., 2010). In contrast, the maximal methanol emission rate observed at the LTO site was twice as high as that reported for white clover (Custer and Schade, 2007). Maize field BVOC exchanges therefore seem to be smaller that those for other crops grown in Europe, but this result should be further confirmed by other BVOC exchanges studies performed on other crops in our region. 
Table 5. BVOC budget estimated for maize at LTO and on diverse crops over a whole growing season.

\begin{tabular}{lrrrrl}
\hline $\left.\mathrm{g}_{\mathrm{BVOC}} \mathrm{ha}^{-1}\right]$ & & & & & \\
Crop & Methanol & Acetaldehyde & Acetone & Acetic acid & Author \\
\hline Maize & $960 \pm 29$ & $-70 \pm 9$ & $-1 \pm 8$ & $-181 \pm 8$ & This study \\
& $5521^{\mathrm{a}}$ & $1075^{\mathrm{a}}$ & $838^{\mathrm{a}}$ & $2251^{\mathrm{a}}$ & Graus et al. (2013) \\
Elephant grass & 20000 & 30000 & 37000 & & Crespo et al. (2013) \\
Miscanthus & $3780^{\mathrm{b}}$ & $680^{\mathrm{b}}$ & $1180^{\mathrm{b}}$ & $3580^{\mathrm{b}}$ & Graus et al. (2013) \\
Grassland & $22171^{\mathrm{c}}$ & $101^{\mathrm{c}}$ & $200^{\mathrm{c}}$ & & Bamberger et al. (2014) \\
\hline
\end{tabular}

\footnotetext{
${ }^{a}$ Original data in $\mathrm{g}_{\mathrm{BVOC}} \mathrm{L}_{\text {ethanol }}^{-1}$. Converted with an ethanol yield of $0.38 \mathrm{~L}_{\text {ethanol }} \mathrm{kg}_{\text {grain }}^{-1}$, a grain : residue ratio equal to $1: 1$, and a biomass yield of $9.59 \mathrm{Mg} \mathrm{ha}^{-1}$, as used by Graus et al. (2013).

${ }^{b}$ Original data in $\mathrm{g}_{\mathrm{BVOC}} \mathrm{L}_{\text {ethanol }}^{-1}$. Converted with an ethanol yield of $0.4 \mathrm{~L}_{\text {ethanol }} \mathrm{kg}_{\text {leaves }}^{-1}$ and a leaf biomass of $5 \mathrm{Mg} \mathrm{ha}^{-1}$, as used by Graus et al. (2013).

${ }^{c}$ Annual budget. Average of 2009 and 2011 budgets for methanol, 2009 budget only for other compounds. Original data in $\mathrm{mg} \mathrm{C} \mathrm{m}{ }^{-2} \mathrm{yr}^{-1}$, converted with the molar mass of each individual compound.

Notice that budgets reported for grassland include both growing periods and cutting events.
}

\subsection{BVOCs exchanged by a maize field under standard environmental conditions}

Up-scaling models (Guenther et al., 2012 for MEGAN v2.1; Lathière et al., 2006 for ORCHIDEE) consider BVOC emissions from growing plants as a function of (i) an SEF that represents the mean emission of a particular plant functional type under standard environmental conditions, and (ii) a multiplicative factor depending on PPFD, $T$ and plant phenology, which reflects the response in emissions to varying environmental conditions.

The SEF values used in current up-scaling models for $\mathrm{C} 4$ crops do not match those observed at the LTO site for any model or any compound (Table 6). In particular, the SEF values used for isoprene and monoterpenes were several orders of magnitude lower at LTO than those used by models. This difference was even greater for isoprene because the M69 signal was associated with isoprene for SEF computation at LTO, whereas it was probably not solely due to isoprene (Sect. 2.2). The SEF value measured at LTO for methanol was 2-4 times lower than that used by up-scaling models, while the SEF value measured for acetaldehyde was 0-11 times lower. The SEF values measured for acetone and acetic acid on our site were respectively 2 and 10 times lower than values used by MEGAN v2.1, and 2 and 5 times higher than values used by ORCHIDEE.

\subsection{Implications for BVOC exchanges from croplands and use of SEFs measured at LTO by up-scaling models}

Given the discrepancies between the SEF values used by the up-scaling models for the $\mathrm{C} 4$ crops and those measured on maize at LTO, one may wonder to which extent these differences could affect the estimations of cropland BVOC budget, and whether the SEF obtained in this study should be implemented in the models to represent $(\mathrm{C} 4)$ croplands.
First, maize is the second most important crop and the most important $\mathrm{C} 4$ crop worldwide (FAOSTATS), accounting for 13 and $67 \%$ of the total cultivated area, respectively. Particularly, in north-western Europe, it accounts for 12 and $99 \%$ of the total/C4 crop cultivated area, respectively. This crop is thus of major importance when evaluating the importance of agricultural ecosystems. Particularly, the C4 crop plant functional type can be realistically equated with maize in northwest Europe.

Then, despite the importance of maize in agricultural lands, SEF currently estimated for croplands (and also C4 croplands) do not rely on BVOC measurements performed on maize. For example, with regard to methanol, Stavrakou et al. (2011) used only one SEF derived from alfalfa for all croplands, although this species accounts for only $1 \%$ of the cultivated area worldwide (FAOSTATS). In particular, for Europe there is a comprehensive SEF inventory (Karl et al., 2009). Karl et al. (2009) mentioned, however, that because of the lack of information for croplands, the SEFs for those ecosystems are default values, i.e. values assigned by databases and up-scaling models from SEF observed on other ecosystems. Consequently, the SEF currently assigned for the $\mathrm{C} 4$ crop PFT are in fact not representative of the actual $\mathrm{C} 4$ crops SEF.

In this study, we provided SEF estimations from a maize field relying on measurements performed under real field conditions. The maize variety grown at LTO was intended for silage (livestock feed) production purposes and the management practices commonly used in this region for this type of crop were thus applied. In addition, the weather conditions during the study were normal for the time and place (normal conditions are defined by the Belgian Royal Meteorological Institute by averaging records taken in Uccle, Belgium over the period 1981-2010. It corresponds to 3.6, 10.1, 17.5 and $10.9^{\circ} \mathrm{C}$ and to $220.5,187.8,224.4$ and $219.9 \mathrm{~mm}$ cumulated precipitation in winter, spring, summer and autumn, respectively). The maize field grown at LTO was thus reasonably representative of the fields of maize grown under real condi- 
Table 6. SEF recorded at LTO under standard environmental conditions and used in up-scaling models for C4 agricultural crops.

\begin{tabular}{|c|c|c|c|c|}
\hline & \multicolumn{2}{|c|}{ This study } & \multirow{2}{*}{$\begin{array}{l}\text { MEGAN v2.1 } \\
{\left[\mu g \mathrm{~m}_{\text {soil }}^{-2} \mathrm{~h}^{-1}\right]}\end{array}$} & \multirow{2}{*}{$\begin{array}{l}\text { ORCHIDEE }^{\mathrm{c}} \\
{\left[\mu \mathrm{gg}_{\mathrm{dw}}^{-1} \mathrm{~h}^{-1}\right]}\end{array}$} \\
\hline & {$\left[\mu \mathrm{g} \mathrm{m}_{\text {soil }}^{-2} \mathrm{~h}^{-1}\right]^{\mathrm{a}}$} & {$\left[\mu \mathrm{gg}_{\mathrm{dw}}^{-1} \mathrm{~h}^{-1}\right]^{\mathrm{b}}$} & & \\
\hline Isoprene & $8^{\mathrm{f}} \pm 5$ & $0.058^{\mathrm{f}} \pm 0.038$ & 200 & 8.500 \\
\hline Monoterpenes & $4 \pm 6$ & $0.030 \pm 0.040$ & 2 & 0.227 \\
\hline Methanol & $231 \pm 19$ & $1.642 \pm 0.137$ & $500^{d} / 800^{e}$ & 2.667 \\
\hline Acetone & $46 \pm 8$ & $0.324 \pm 0.057$ & 80 & 0.113 \\
\hline Acetaldehyde & $7 \pm 9$ & $0.046 \pm 0.065$ & 80 & 0.046 \\
\hline Acetic acid & $8 \pm 9$ & $0.055 \pm 0.072$ & 80 & 0.013 \\
\hline \multicolumn{5}{|c|}{$\begin{array}{l}\text { a Standard environmental conditions chosen to match MEGAN v2.1 standard environmental conditions (Guenther } \\
\text { et al., 2012): } 28^{\circ} \mathrm{C} \leq T^{\circ} \leq 32{ }^{\circ} \mathrm{C} ; \mathrm{PPFD} \geq 1000 \mu \mathrm{mol} \mathrm{m}^{-2} \mathrm{~s}^{-1} ; 4.38 \mathrm{~m}^{2} \mathrm{~m}^{-2} \leq \mathrm{LAI} \leq 5.04 \mathrm{~m}^{2} \mathrm{~m}^{-2} \text {. }\end{array}$} \\
\hline \multicolumn{5}{|c|}{$\begin{array}{l}\text { b Specific leaf weight used for the conversion from } \mathrm{m}_{\text {soil }}^{-2} \text { to } \mathrm{g}_{\mathrm{dw}}^{-1}: 29.0 \mathrm{~g}_{\mathrm{dw}, \text { leaf }} \mathrm{m}_{\mathrm{leaf}}^{-2} \text { (meas. performed on a mature } \\
\text { maize leaf of variety Prosil; A. Mozaffar et al., personal communication, 2015). LAI used for conversion: } \\
4.85 \mathrm{~m}^{2} \mathrm{~m}^{-2} \text {. } \\
{ }^{c} \text { Lathière et al. (2006). SEF are here given in } \mu \mathrm{g}_{\text {Compound }} \text { instead of } \mu \mathrm{g}_{\mathrm{C}} \text {. }\end{array}$} \\
\hline Guenther et al. (201 & & & & \\
\hline
\end{tabular}

tions in the Hesbaye region of Belgium and, by extension, in northwest Europe, where maize is grown under similar pedoclimatic conditions (i.e., temperate maritime climate and silt or sandy-loamy soils) and for similar production purposes (i.e., farms with crops and livestock).

Therefore, in the absence of any robustly established SEF for $\mathrm{C} 4$ crop so far, we would suggest modelers to use the SEF determined at LTO for the C4 crop PFT instead of the current estimations. As the BVOC exchange rates measured on our site strongly differed from other maize studies performed on other sites, though, we also want to make them aware that SEF obtained in this study are likely not valid outside NW Europe and should therefore not be used in other world regions. We also recommend additional BVOC measurement studies performed on maize fields located in other NW European sites to validate the spatial extent of the values proposed in this paper.

\section{Conclusions}

This work constitutes the first BVOC study performed in a maize field over a whole growing season. It showed that the maize field emitted mainly methanol. Smaller but significant bi-directional OVOC exchanges were also recorded, resulting in a net emission of methanol and MEK and in a net uptake of acetic acid, acetaldehyde and MVK+MACR during the maize growing season. Terpenes exchange (mostly emissions) and a small but significant benzene and toluene uptake were also observed. Exchanges occurred throughout the growing season and each compound had different dynamics.

The observations at LTO showed in particular that (i) the soil was an important methanol and acetaldehyde source, and an important acetic acid sink; (ii) the BVOC exchanges were much lower than in other maize field studies, even when normalized by $T$, PPFD and phenology; (iii) they were also lower than those of other crops grown in Europe; and (iv) the estimated SEFs were much lower than those currently used by up-scaling models for the $\mathrm{C} 4$ crop plant functional type, of which maize is the main species.

Soil BVOC exchanges were as important, if not more so, as plant BVOC exchanges when the soil was bare and they decreased when maize was grown. The contribution of soil exchanges was probably particularly important on our site because BVOC exchanged by maize at LTO were small compared with those reported for other crops and grasses. Nevertheless, this work demonstrates that soil is a major actor in ecosystem-scale BVOC exchanges for some ecosystems. Future ecosystem-scale BVOC studies, particularly those investigating croplands, should therefore consider soil as a potential major BVOC reservoir. In addition, the BVOC exchange mechanisms between agricultural soils and the atmosphere need to be better understood in order to find out why these exchanges decrease during the maize growing season.

Maize is cultivated in many regions of the world and is the main species of the $\mathrm{C} 4$ crop plant functional type. Our results showed that the normalization of BVOC exchanges by $T$, PPFD and phenology was not enough to explain the huge difference in BVOC exchange rates among maize studies in different parts of the world. Modelers should therefore be aware of the current large uncertainties in BVOC exchange rates for this crop.

However, given (i) the good representativity of the maize field grown at LTO in terms of management practices and of weather conditions typical of NW Europe, and (ii) the current absence of maize in SEF assignments for C4 crops by models, which contradicts with the major importance of that crop for that PFT, we would still suggest modelers using SEF values proposed in this paper for NW Europe. The lower SEF values observed on our site in comparison with those currently used by up-scaling models - in particular for terpenes - would then suggest an over-estimation of BVOC exchanges from $\mathrm{C} 4$ agricultural ecosystems in this region. This could 
result in larger terpenes emission changes than currently estimated when converting forested ecosystems to agricultural lands.

In contrast, the strong discrepancies in the BVOC exchange rates among studies performed in different world regions indicate that they are not extrapolable from one region to another. As a result, maize SEF and BVOC budget determined at LTO are likely not representative of other world regions (and by extension of the global scale) and should therefore be evaluated for each important agronomic region by conducting long-term BVOC measurement studies similar to this one and by using the maize varieties and management practices commonly used in these regions. Besides, BVOC and specifically OVOC exchange mechanisms between maize fields and the atmosphere also need to be better understood in order to identify the reasons for the huge differences in normalized BVOC exchange rates observed among maize studies and to discover if they behave according to up-scaling model algorithms beyond the standard conditions (Niinemets et al., 2014). Given that each investigated compound had different exchange dynamics, mechanisms need to be evaluated separately for each compound, particularly for methanol which has been consistently shown as the compound dominating the exchanges.

Finally, future research should also focus on other crops in order to extend the comparison. For Europe, in particular, BVOC exchanges should be measured for winter wheat because, in terms of cultivated area, it is the most important crop in our region (FAOSTATS).

Acknowledgements. The authors wish to thank Frédéric Wilmus, Henri Chopin and Alain Debacq for BVOC set-up installation and station monitoring, the farmer Philippe Van Eyck, the LonzéeICOS team for site follow-up and measurement of environmental parameters. Aurélie Bachy holds a Research Fellow Grant from the FRS-FNRS, Belgium (A215-MCF/DM-A362 FC 95918). This research has also been facilitated by the CROSTVOC project (T.0086.13) also funded by the FRS-FNRS.

Edited by: L. Zhang

\section{References}

Ammann, C., Brunner, A., Spirig, C., and Neftel, A.: Technical note: Water vapour concentration and flux measurements with PTR-MS, Atmos. Chem. Phys., 6, 4643-4651, doi:10.5194/acp6-4643-2006, 2006.

Aubinet, M., Grelle, A., Ibrom, A., Rannik, U., Moncrieff, J., Foken, T., Kowalski, A. S., Martin, P. H., Berbigier, P., Bernhofer, C., Clement, R., Elbers, J., Granier, A., Grünwald, T., Morgenstern, K., Pilegaard, K., Rebmann, C., Snijders, W., Valentini, R., and Vesala, T.: Estimates of the Annual Net Carbon and Water Exchange of Forests: The EUROFLUX Methodology, Adv. Ecol. Res., 30, 113-175, 1999.
Aubinet, M., Moureaux, C., Bodson, B., Dufranne, D., Heinesch, B., Suleau, M., Vancutsem, F., and Vilret, A.: Carbon sequestration by a crop over a 4-year sugar beet/winter wheat/seed potato/winter wheat rotation cycle, Agr. Forest Meteorol., 149, 407-418, 2009.

Aubinet, M., Vesala, T., and Papale, D.: Eddy covariance a practical guide to measurement and data analysis, Springer, Dordrecht, New York, 2012.

Bamberger, I., Hörtnagl, L., Schnitzhofer, R., Graus, M., Ruuskanen, T. M., Müller, M., Dunkl, J., Wohlfahrt, G., and Hansel, A.: BVOC fluxes above mountain grassland, Biogeosciences, 7, 1413-1424, doi:10.5194/bg-7-1413-2010, 2010.

Bamberger, I., Hörtnagl, L., Walser, M., Hansel, A., and Wohlfahrt, G.: Gap-filling strategies for annual VOC flux data sets, Biogeosciences, 11, 2429-2442, doi:10.5194/bg-11-2429-2014, 2014.

Bellarby, J., Wattenbach, M., Tuck, G., Glendining, M. J., and Smith, P.: The potential distribution of bioenergy crops in the UK under present and future climate, Biomass Bioenerg., 34, 19351945, 2010.

Copeland, N., Cape, J. N., and Heal, M. R.: Volatile organic compound emissions from Miscanthus and short rotation coppice willow bioenergy crops, Atmos. Environ., 60, 327-335, 2012.

Crespo, E., Graus, M., Gilman, J. B., Lerner, B. M., Fall, R., Harren, F. J. M., and Warneke, C.: Volatile organic compound emissions from elephant grass and bamboo cultivars used as potential bioethanol crop, Atmos. Environ., 65, 61-68, 2013.

Custer, T. and Schade, G.: Methanol and acetaldehyde fluxes over ryegrass, Tellus, Ser. B Chem. Phys. Meteorol., 59, 673-684, 2007.

Das, M., Kang, D., Aneja, V. P., Lonneman, W., Cook, D. R., and Wesely, M. L.: Measurements of hydrocarbon air-surface exchange rates over maize, Atmos. Environ., 37, 2269-2277, 2003.

Eller, A. S. D., Sekimoto, K., Gilman, J. B., Kuster, W. C., de Gouw, J. A., Monson, R. K., Graus, M., Crespo, E., Warneke, C., and Fall, R.: Volatile organic compound emissions from switchgrass cultivars used as biofuel crops, Atmos. Environ., 45, 3333-3337, 2011.

Foken, T. and Wichura, B.: Tools for quality assessment of surfacebased flux measurements, Agr. Forest Meteorol., 78, 83-105, doi:10.1016/0168-1923(95)02248-1, 1996.

Fowler, D., Pilegaard, K., Sutton, M. A., Ambus, P., Raivonen, M., Duyzer, J., Simpson, D., Fagerli, H., Fuzzi, S., Schjoerring, J. K., Granier, C., Neftel, A., Isaksen, I. S. A., Laj, P., Maione, M., Monks, P. S., Burkhardt, J., Daemmgen, U., Neirynck, J., Personne, E., Wichink-Kruit, R., Butterbach-Bahl, K., Flechard, C., Tuovinen, J. P., Coyle, M., Gerosa, G., Loubet, B., Altimir, N., Gruenhage, L., Ammann, C., Cieslik, S., Paoletti, E., Mikkelsen, T. N., Ro-Poulsen, H., Cellier, P., Cape, J. N., Horváth, L., Loreto, F., Niinemets, U., Palmer, P. I., Rinne, J., Misztal, P., Nemitz, E., Nilsson, D., Pryor, S., Gallagher, M. W., Vesala, T., Skiba, U., Brüggemann, N., Zechmeister-Boltenstern, S., Williams, J., O’Dowd, C., Facchini, M. C., de Leeuw, G., Flossman, A., Chaumerliac, N., and Erisman, J. W.: Atmospheric composition change: Ecosystems-Atmosphere interactions, Atmos. Environ., 43, 5193-5267, 2009.

Fry, M. M., Naik, V., West, J. J., Schwarzkopf, M. D., Fiore, A. M., Collins, W. J., Dentener, F. J., Shindell, D. T., Atherton, C., Bergmann, D., Duncan, B. N., Hess, P., MacKenzie, I. A., Marmer, E., Schultz, M. G., Szopa, S., Wild, O., and 
Zeng, G.: The influence of ozone precursor emissions from four world regions on tropospheric composition and radiative climate forcing, J. Geophys. Res. Atmos., 117, D07306, doi:10.1029/2011JD017134, 2012.

Graus, M., Eller, A. S. D., Fall, R., Yuan, B., Qian, Y., Westra, P., de Gouw, J., and Warneke, C.: Biosphere-atmosphere exchange of volatile organic compounds over $\mathrm{C} 4$ biofuel crops, Atmos. Environ., 66, 161-168, 2013.

Guenther, A. B., Jiang, X., Heald, C. L., Sakulyanontvittaya, T., Duhl, T., Emmons, L. K., and Wang, X.: The Model of Emissions of Gases and Aerosols from Nature version 2.1 (MEGAN2.1): an extended and updated framework for modeling biogenic emissions, Geosci. Model Dev., 5, 1471-1492, doi:10.5194/gmd-51471-2012, 2012.

Hardacre, C. J., Palmer, P. I., Baumanns, K., Rounsevell, M., and Murray-Rust, D.: Probabilistic estimation of future emissions of isoprene and surface oxidant chemistry associated with land-use change in response to growing food needs, Atmos. Chem. Phys., 13, 5451-5472, doi:10.5194/acp-13-5451-2013, 2013.

Hörtnagl, L., Clement, R., Graus, M., Hammerle, A., Hansel, A., and Wohlfahrt, G.: Dealing with disjunct concentration measurements in eddy covariance applications: A comparison of available approaches, Atmos. Environ., 44, 2024-2032, 2010.

Inomata, S. and Tanimoto, H.: A Quantitative Examination of the Detection Sensitivities of Proton-Transfer Reaction Mass Spectrometry for Gaseous 2Propanol and Acetic Acid, Bull. Chem. Soc. Jpn., 83, 900-904, doi:10.1246/bcsj.20100043, 2010.

Isaksen, I. S. A., Granier, C., Myhre, G., Berntsen, T. K., Dalsøren, S. B., Gauss, M., Klimont, Z., Benestad, R., Bousquet, P., Collins, W., Cox, T., Eyring, V., Fowler, D., Fuzzi, S., Jöckel, P., Laj, P., Lohmann, U., Maione, M., Monks, P., Prevot, A. S. H., Raes, F., Richter, A., Rognerud, B., Schulz, M., Shindell, D., Stevenson, D. S., Storelvmo, T., Wang, W. C., van Weele, M., Wild, M., and Wuebbles, D.: Atmospheric composition change: Climate-Chemistry interactions, Atmos. Environ., 43, 5138-5192, 2009.

Kaimal, J. C. and Finnigan, J. J.: Atmospheric boundary layer flows: their structure and measurement, Oxford University Press, USA, 1994.

Karl, M., Guenther, A., Köble, R., Leip, A., and Seufert, G.: A new European plant-specific emission inventory of biogenic volatile organic compounds for use in atmospheric transport models, Biogeosciences, 6, 1059-1087, doi:10.5194/bg-6-1059-2009, 2009.

Karl, T., Guenther, A., Lindinger, C., Jordan, A., Fall, R. and Lindinger, W.: Eddy covariance measurements of oxygenated volatile organic compound fluxes from crop harvesting using a redesigned proton-transfer-reaction mass spectrometer, J. Geophys. Res. Atmos., 106(D20), 24157-24167, doi:10.1029/2000jd000112, 2001.

Karl, T., Harren, F., Warneke, C., de Gouw, J., Grayless, C., and Fall, R.: Senescing grass crops as regional sources of reactive volatile organic compounds, J. Geophys. Res. Atmos., 110, D15302, doi:10.1029/2005JD005777, 2005.

Konig, G., Brunda, M., Puxbaum, H., Hewitt, C. N., Duckham, S. C., and Rudolph, J.: Relative contribution of oxygenated hydrocarbons to the total biogenic VOC emissions of selected midEuropean agricultural and natural plant species, Atmos. Environ., 29, 861-874, 1995.
Laffineur, Q., Aubinet, M., Schoon, N., Amelynck, C., Müller, J.F., Dewulf, J., Van Langenhove, H., Steppe, K., and Heinesch, B.: Abiotic and biotic control of methanol exchanges in a temperate mixed forest, Atmos. Chem. Phys., 12, 577-590, doi:10.5194/acp-12-577-2012, 2012.

Langford, B., Acton, W., Ammann, C., Valach, A., and Nemitz, E.: Eddy-covariance data with low signal-to-noise ratio: time-lag determination, uncertainties and limit of detection, Atmos. Meas. Tech., 8, 4197-4213, doi:10.5194/amt-8-4197-2015, 2015.

Lathière, J., Hauglustaine, D. A., Friend, A. D., De NobletDucoudré, N., Viovy, N., and Folberth, G. A.: Impact of climate variability and land use changes on global biogenic volatile organic compound emissions, Atmos. Chem. Phys., 6, 2129-2146, doi:10.5194/acp-6-2129-2006, 2006.

Lerdau, M. and Slobodkin, L.: Trace gas emissions and speciesdependent ecosystem services, Trends Ecol. Evol., 17, 309-312, doi:10.1016/S0169-5347(02)02535-1, 2002.

Meier, U.: Growth stages of mono-and dicotyledonous plants, BBCH Monograph, 2nd Edn., Federal Biological Research Centre for Agriculture and Forestry, 2001.

Moncrieff, J. B., Massheder, J. M., De Bruin, H., Elbers, J., Friborg, T., Heusinkveld, B., Kabat, P., Scott, S., Soegaard, H., and Verhoef, A.: A system to measure surface fluxes of momentum, sensible heat, water vapour and carbon dioxide, J. Hydrol., 188189, 589-611, 1997.

Monson, R. K., Jones, R. T., Rosenstiel, T. N., and Schnitzler, J. P.: Why only some plants emit isoprene, Plant Cell Environ., 36, 503-516, 2013.

Moureaux, C., Debacq, A., Bodson, B., Heinesch, B., and Aubinet, M.: Annual net ecosystem carbon exchange by a sugar beet crop, Agr. Forest Meteorol., 139, 25-39, 2006.

Neftel, A., Spirig, C., and Ammann, C.: Application and test of a simple tool for operational footprint evaluations, Environ. Pollut., 152, 644-652, 2008.

Niinemets, Ü., Monson, R. K., and SpringerLink: Biology, Controls and Models of Tree Volatile Organic Compound Emissions, Springer Netherlands, Imprint: Springer, Dordrecht, 2013.

Niinemets, Ü., Fares, S., Harley, P. and Jardine, K. J.: Bidirectional exchange of biogenic volatiles with vegetation: emission sources, reactions, breakdown and deposition, Plant Cell Environ., 37, 1790-1809, doi:10.1111/pce.12322, 2014.

Osborne, B., Saunders, M., Walmsley, D., Jones, M., and Smith, P.: Key questions and uncertainties associated with the assessment of the cropland greenhouse gas balance, Agr. Ecosyst. Environ., 139, 293-301, 2010.

Park, J.-H., Fares, S., Weber, R., and Goldstein, A. H.: Biogenic volatile organic compound emissions during BEARPEX 2009 measured by eddy covariance and flux-gradient similarity methods, Atmos. Chem. Phys., 14, 231-244, doi:10.5194/acp-14-2312014, 2014.

Peñuelas, J., Asensio, D., Tholl, D., Wenke, K., Rosenkranz, M., Piechulla, B., and Schnitzler, J. P.: Biogenic volatile emissions from the soil, Plant Cell Environ., 37, 1866-1891, 2014.

Ruuskanen, T. M., Müller, M., Schnitzhofer, R., Karl, T., Graus, M., Bamberger, I., Hörtnagl, L., Brilli, F., Wohlfahrt, G., and Hansel, A.: Eddy covariance VOC emission and deposition fluxes above grassland using PTR-TOF, Atmos. Chem. Phys., 11, 611-625, doi:10.5194/acp-11-611-2011, 2011. 
Sartelet, K. N., Couvidat, F., Seigneur, C., and Roustan, Y.: Impact of biogenic emissions on air quality over Europe and North America, Atmos. Environ., 53, 131-141, doi:10.1016/j.atmosenv.2011.10.046, 2012.

Schade, G. W. and Custer, T. G.: OVOC emissions from agricultural soil in northern Germany during the 2003 European heat wave, Atmos. Environ., 38, 6105-6114, doi:10.1016/j.atmosenv.2004.08.017, 2004.

Schwarz, K., Filipiak, W., and Amann, A.: Determining concentration patterns of volatile compounds in exhaled breath by PTR-MS, J. Breath Res., 3, 027002, doi:10.1088/17527155/3/2/027002, 2009.

Spirig, C., Neftel, A., Ammann, C., Dommen, J., Grabmer, W., Thielmann, A., Schaub, A., Beauchamp, J., Wisthaler, A., and Hansel, A.: Eddy covariance flux measurements of biogenic VOCs during ECHO 2003 using proton transfer reaction mass spectrometry, Atmos. Chem. Phys., 5, 465-481, doi:10.5194/acp-5-465-2005, 2005.

Stavrakou, T., Guenther, A., Razavi, A., Clarisse, L., Clerbaux, C., Coheur, P.-F., Hurtmans, D., Karagulian, F., De Mazière, M., Vigouroux, C., Amelynck, C., Schoon, N., Laffineur, Q., Heinesch, B., Aubinet, M., Rinsland, C., and Müller, J.-F.: First space-based derivation of the global atmospheric methanol emission fluxes, Atmos. Chem. Phys., 11, 4873-4898, doi:10.5194/acp-11-4873-2011, 2011.

$\mathrm{Su}, \mathrm{T}$.: Parametrization of kinetic energy dependences of ion-polar molecule collision rate constants by trajectory calculations, J. Chem. Phys., 100, 4703, doi:10.1063/1.466255, 1994.

Taipale, R., Ruuskanen, T. M., and Rinne, J.: Lag time determination in DEC measurements with PTR-MS, Atmos. Meas. Tech., 3, 853-862, doi:10.5194/amt-3-853-2010, 2010.
Tani, A., Tobe, S., and Shimizu, S.: Uptake of methacrolein and methyl vinyl ketone by tree saplings and implications for forest atmosphere, Environ. Sci. Technol., 44, 7096-7101, 2010.

Tsimpidi, A. P., Trail, M., Hu, Y., Nenes, A., and Russell, A. G.: Modeling an air pollution episode in northwestern United States: Identifying the effect of nitrogen oxide and volatile organic compound emission changes on air pollutants formation using direct sensitivity analysis, J. Air Waste Manage., 62, 1150-1165, 2012.

Warneke, C., Luxembourg, S. L., De Gouw, J. A., Rinne, H. J. I., Guenther, A. B., and Fall, R.: Disjunct eddy covariance measurements of oxygenated volatile organic compounds fluxes from an alfalfa field before and after cutting, J. Geophys. Res.-Atmos., 107, 1-6, doi:10.1029/2001JD000594, 2002.

White, M. L., Russo, R. S., Zhou, Y., Ambrose, J. L., Haase, K., Frinak, E. K., Varner, R. K., Wingenter, O. W., Mao, H., Talbot, R., and Sive, B. C.: Are biogenic emissions a significant source of summertime atmospheric toluene in the rural Northeastern United States?, Atmos. Chem. Phys., 9, 81-92, doi:10.5194/acp9-81-2009, 2009.

Williams, J. E., van Velthoven, P. F. J., and Brenninkmeijer, C. A. M.: Quantifying the uncertainty in simulating global tropospheric composition due to the variability in global emission estimates of Biogenic Volatile Organic Compounds, Atmos. Chem. Phys., 13, 2857-2891, doi:10.5194/acp-13-2857-2013, 2013.

Ziemann, P. J. and Atkinson, R.: Kinetics, products, and mechanisms of secondary organic aerosol formation, Chem. Soc. Rev., 41, 6582-6605, 2012. 